\title{
The Status of Librarians in Four-Year State Colleges and Universities
}

This study developed from the efforts of librarians at the four-year campuses and university centers of the State University of New York to gain complete faculty status. The paper is based on the replies from a questionnaire sent to 321 four-year state colleges and university centers across the United States. The compilation of statistics is based on a 57 per cent return. Status for librarians was equated with that of the academic faculties in regard to rank and titles, promotion criteria, tenure, sabbatical leave, rates of pay, holidays and vacations, participation in faculty government, and fringe benefits.

$\mathrm{T}$ HE COLLEGE LIBRARIAN is no longer regarded (if he ever was) as simply a keeper of musty collections of books. He has had to make his own contributions to the new methods of information dissemination and to new approaches to research and teaching. As academic requisites have risen through the years, the qualifications of librarians have had to keep pace with the demands of the academic world of the twentieth century. In a number of colleges and universities throughout the country the librarian is now, as a result, accepted as a member of the faculty, with concomitant duties and responsibilities. He teaches, conducts research, publishes, serves on important faculty committees, and often occupies an influential seat in the faculty senate.

This is true, however, of only a very limited number of schools. In most places, the college librarian has remained in academic limbo. $\mathrm{He}$ has

Mrs. Madan is Head of Acquisitions, Mrs. Hetler is Head of Periodicals, and Miss Strong is Head of Reference at the Library of State University of New York College at Brockport. heeded the rapidly increasing demands for better training, greater specialization, and more versatility, but his own demands for equal status have not been accorded the same attention. The results have been what one might have expected. In those colleges and universities where equality of status is not granted, the college librarian has become a scarce commodity, a vanishing species. Despite some breakthroughs, progress toward equality of status has been exceedingly slow. Robert B. Downs, in a 1958 monograph, was able to report only little progress throughout the country in the direction of improved status. ${ }^{1}$ Nine years later, R. Dean

Galloway wrote:

A college can no more achieve excellence without an excellent faculty. In fact, it can't even build an excellent faculty without first having an excellent library. Yet the architect of library excellence-the professional librarian-has been so neglected that there is now an acute national shortage, and in most college libraries there is a crisis in recruiting qualified librarians. This

1 Robert B. Downs, The Status of American College and University Librarians (ACRL Monograph number 22, Chicago: ALA, 1958), 176p. 
crisis is a result of a failure throughout the years to grant status and benefits to librarians that are commensurate with their qualifications and their duties. ${ }^{2}$

As if to prove the truth of Dr. Galloway's statement, the monolithic State University of New York that same spring made an announcement of salary increases that were significantly smaller for librarians than for teaching faculties, despite the fact that State University of New York is plagued with the usual critical shortage of qualified librarians.

The State University of New York system employs about four hundred professional librarians at its twenty-eight colleges and universities. ${ }^{3}$ Inequities in status exist on every campus. Administrators apply the same criteria for librarians' promotions as they do for the teaching faculty, yet they are usually considered as part of the administrative staff, without the rights and privileges of the academics. The ferment for improved status has, however, resulted in the formation of working committees at most of the campuses, and their combined efforts have yielded some results.

In October 1967 the faculty senate of the State University of New York recommended that professional librarians be granted faculty status without faculty titles but with all rights, privileges, and obligations thereof. The Senate advised its Executive Committee to prepare the necessary amendments for the policies of the board of trustees. Further, in its report of February 1968 the State University of New York faculty senate recommended that members of the professional staff of State University of New York libraries be accorded academic appointments and tenure by 1970. These recommendations were approved in to-

\footnotetext{
${ }^{2}$ R. Dean Galloway, "Academic Benefits for Academic Librarians," AAUP Bulletin, LIII (Spring $1967), 61$.

${ }^{3}$ The twenty-eight colleges of the SUNY system consists of four university centers, twelve specialized colleges, two medical centers, and ten four-year colleges. The junior colleges are not included since they operate under different administrative policies.
}

tal on June 12, 1968 by the board of trustees.

The writers of this article, members of the ad hoc committee on faculty status for librarians at the State University College at Brockport, New York (one of ten colleges of arts and sciences in the SUNY system) recently conducted a nationwide survey of four-year colleges and universities to determine the present status of librarians on other state university campuses throughout the country. In preparation for the survey, the following definition of "full faculty status" for librarians was formulated:

'Faculty status' entails complete equality with the academic faculty in regard to rank and titles, promotion criteria, tenure, sabbatical leave, rates of pay, holidays and vacations, representation and participation in faculty government and fringe benefits.

Only when equality in all the above conditions was met did we consider that librarians should be regarded as having "full faculty status."

\section{The Questionnaire ${ }^{4}$}

The survey was limited to four-year state colleges and universities because the committee wanted to compare its situation with sister state institutions throughout the country. New York State four-year colleges and university centers were excluded from the study since recent data were available from a study conducted by the librarians at the Stony Brook campus. ${ }^{5}$ The College Blue Book 6 and American Universities and Colleges ${ }^{7}$ were the sources used to select the list of colleges and universities where the questionnaire would be sent.

The questionnaire consisted of eight

\footnotetext{
4 Composed with the assistance of Dr. Howard Clayton, now with the University of Oklahoma.

5 An informal study on status of the State University of New York librarians conducted by a committee of librarians at State University Center at Stony Brook, July 1967.

The College Blue Book (12th ed.; Los Angeles: College Planning Programs, Ltd., 1968), I, 822p.

${ }^{7}$ American Universities and Colleges (9th ed.; Washington, D.C.: American Council on Education, 1964), 1339p.
} 
TABLE 1

Regional Distribution of Full Academic Status of Librarians in State Universities and Four-Year Colleges

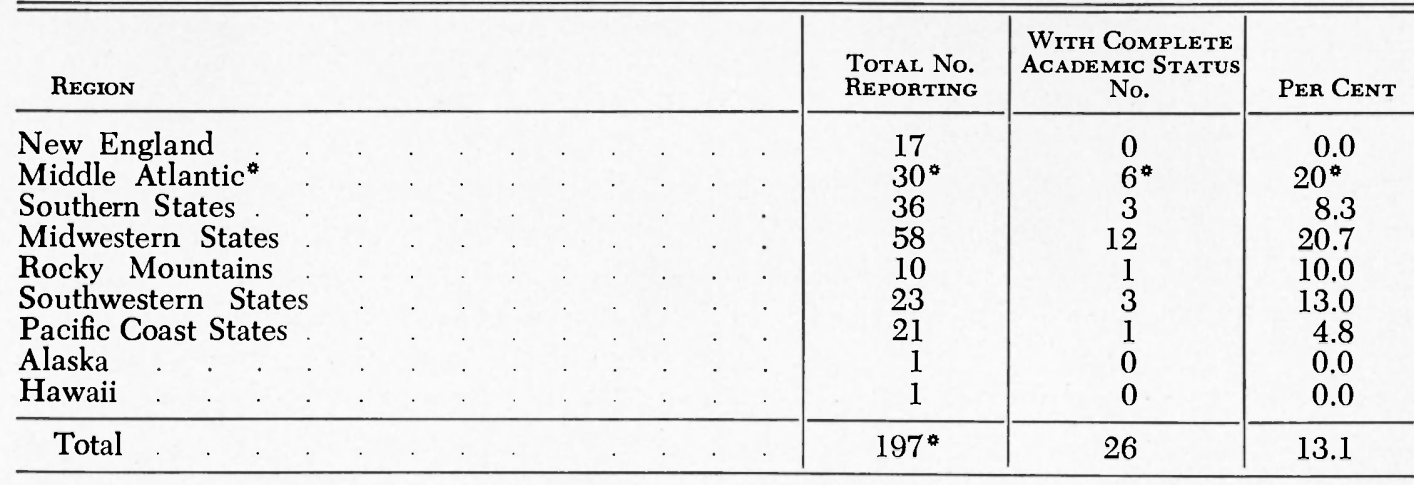

- Including fourteen State University of New York colleges and university centers which were not questioned for this survey since data were obtained prior to the sending of the questionnaire.

major questions designed to establish a comparison between the academic faculty and the librarians of the same institutions. The questions were phrased in such a manner as to establish a valid comparison relevant to the above definition of "full faculty status." The following were asked:

1. Is faculty rank given to librarians, or do they have special titles?

2. What are the criteria for promotion: research, seniority, publications, advanced degrees, teaching, or work performance?

3 . What is required to achieve tenure; are librarians given the same privileges as teaching faculty?

4. Who at the institution is eligible for sabbatical leave, and at what rank?

5. Is the academic appointment for faculty and librarians based on twelve or nine months? Is summer employment optional and separately compensated?

6. Are all academic vacations given to both faculty and librarians?

7. Who participates in the faculty government and who has voting rights and representation?

8. What are the fringe benefits and to whom are they given?

At the end of the questionnaire the li- brarians' evaluation was solicited regarding the degree of status they had attained in their own institution, and further comments were requested.

The questionnaires were sent to 321 colleges and universities throughout the United States in October 1967. Two hundred returns (62.3 per cent) were received, of which the committee was able to analyze 183, giving a return of 57 per cent. Many replies were received in the form of letters. The questionnaire was subsequently registered with the American Council on Education and assigned No. QR5544.

The last step in the investigation involved the tabulation and interpretation of the results. To make the analysis of data more efficient, a code sheet was set up and the answers transcribed into numerical values. The values were converted into IBM readable data. The data processing division at State University of New York College at Brockport assisted in analysis of the data.

\section{Findings}

The statistical analysis shows that only twenty-six of 183, or 14.2 per cent, of the reporting libraries grant "full faculty status" to librarians. The low 14.2 per cent figure was a result of strict adherence to the definition of "full faculty 
status." To qualify under the definition an institution had to allow its librarians equality in all categories. Twenty-one libraries which showed slight deviations were therefore accounted as not having "full faculty status." These libraries varied in only one of the following areas: librarians were not permitted, expected, or encouraged to engage in research; to teach credit-carrying courses; to take complete academic vacations; or to participate fully in faculty government. If these variations had been allowed, the figure for reporting libraries with faculty status would have been 25.7 per cent. The last question of the questionnaire dealt with the self-evaluation of the respondents as to whether or not they felt they had full faculty status at their particular institution. The answers to this question were very revealing: almost two-thirds, or 63.4 per cent, of the reporting librarians consider themselves as having full faculty status, but only 14.2 per cent of the total answering met our criteria of "full faculty status." The high percentage of librarians reporting that they had full faculty status might be attributed to the fact that librarians themselves are not aggressive in this area. They do not expect or demand equal treatment from their institutions nor do they see themselves in the same profes- sional light as the rest of the academic faculty.

To establish Table 1, the total responses were sorted by regions to ascertain if any pattern of distribution could be detected. In order not to distort the regional results, information was included on State University of New York university centers and four-year colleges which had been obtained by questionnaire prior to this particular study.

As shown in Figure 1 a regional fluctuation did emerge. The midwestern region, represented by the largest number of responses, fifty-eight, had also the highest percentage, 20.7 per cent, of institutions with "full faculty status." The midwestern region consisted of Michigan, Ohio, Wisconsin, Indiana, Illinois, Minnesota, Nebraska, Iowa, Missouri, North and South Dakota, and Kansas. Next followed the middle Atlantic states with 20 per cent. Six regions had representation among the librarians with "full faculty status," while three regions, New England, Alaska, and Hawaii reported no institutions that could fulfill the established criteria. Surprisingly, there was not a single institution in the New England area reporting "full faculty status." As one librarian from New England reported, "I have had just one fully qualified person on my staff in the

Fig. 1-Pattern of Regional Distribution: Per Cent with Complete Academic Status

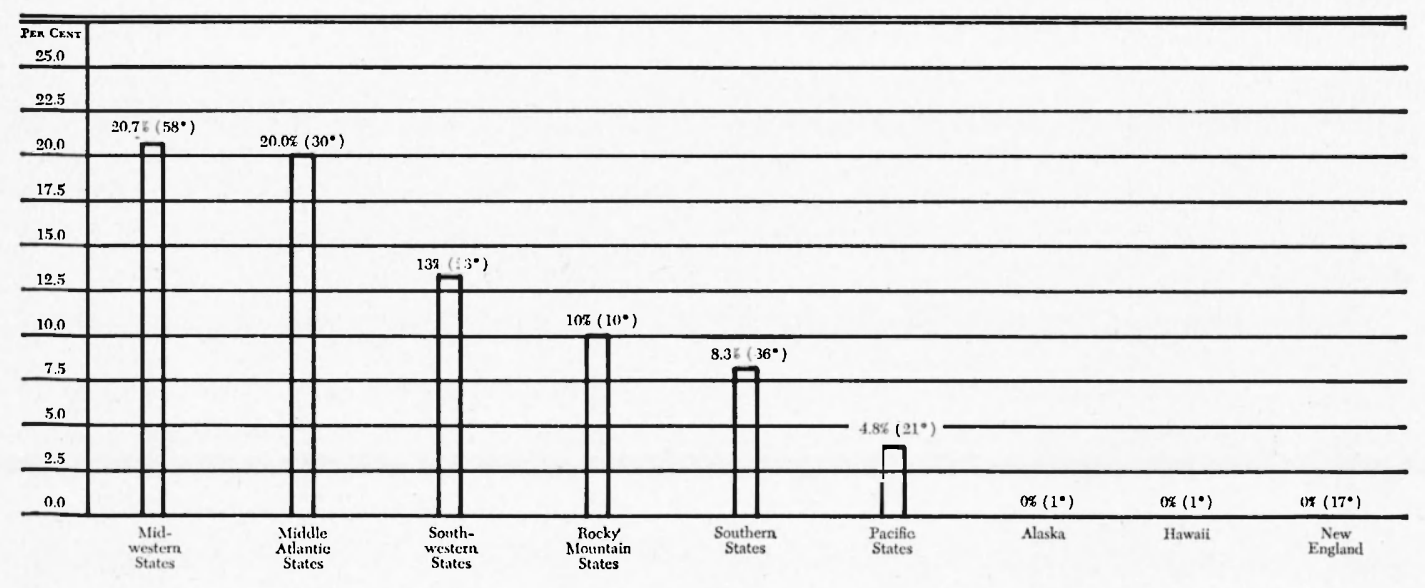


TABLE 2

Statistical Analysis of Questionnaire by Major Criteria

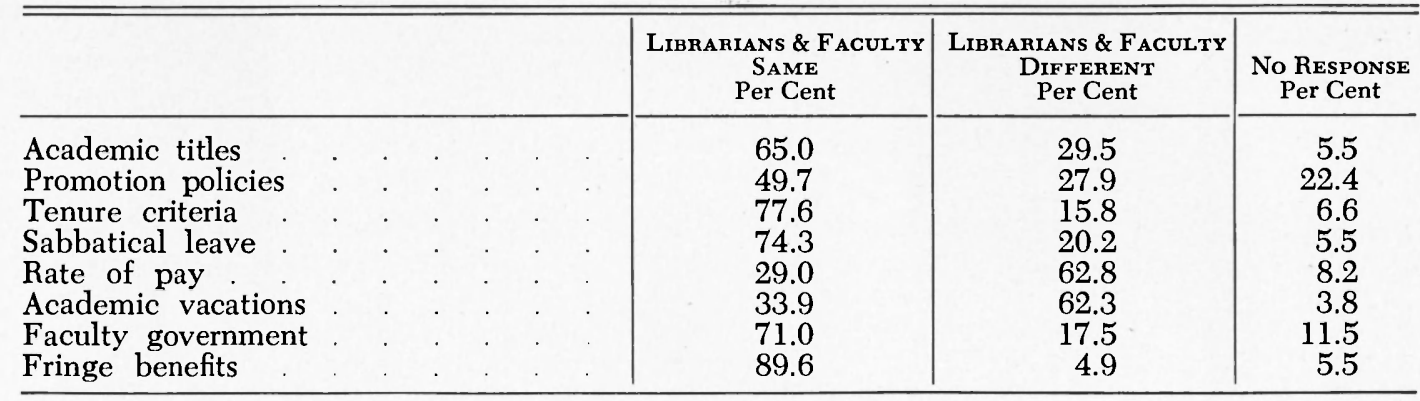

fourteen years I have been here and lost that one to a neighboring university where status is given."

After the tabulation of data for regional distribution was completed, an effort was made to find out if the size of the institution would have any bearing on "full faculty status." The responses were divided into three categories according to the size of the student population. The first group consisted of colleges with four thousand or fewer students, the second of those between 4,001 to 12,000 students, and the third group included all the colleges with 12,001 students and above. Computing all variables, the result was consistent. The middle group of colleges (those having between 4,001 and 12,000 students) had the highest frequency of "full faculty status." Examples of this finding are the state university systems of Pennsylvania, New Jersey, and Missouri, where the large universities do not have full faculty status but the four-year institutions do. The study indicated that middle-sized institutions are ahead of their larger and smaller sister institutions in giving recognition to the library profession.

Table 2 reflects the over-all comparison of librarians to faculty within the framework established by the aforementioned definition of "full faculty status." It should be noted that among the privileges given to librarians, fringe benefits and participation in faculty government occur most frequently, with tenure, sab- batical leave, and academic titles ranking next. Faculty promotion policies, academic vacations, and rate of pay, in that order, are less often available to librarians. The area of least equality was rate of pay, with only 29.0 per cent of respondents being equal. The next lowest area was that of academic vacations, with 33.9 per cent of respondents being equal. It is interesting to note that although 65.0 per cent of librarians have academic titles, such titles do not guarantee equal privileges since only 29.0 per cent have the same rate of pay as the faculty. Almost half of the libraries reporting, 49.7 per cent, indicated that the staff is judged for promotion by the same criteria as faculty, including research and publications. However, only 33.9 per cent of librarians have equal vacations.

It is apparent from Table 3 that in 74.9 per cent of the libraries reporting, work performance is most frequently used as a criterion for promotion. To put it differently, an overwhelming threefourths of the libraries reporting still attach significant importance to work performance. Almost two-thirds, or 63.4 per cent, of the libraries consider advanced degrees as the second most frequently used factor for evaluation of professional librarians. Seniority, which only a decade ago would have topped the list, interestingly enough ranks third in order of frequency with 43.2 per cent. A glance at the table reveals that only 
TABLE 3

Criteria Used for Promotions of Academic

Librarians in Descending Order of Frequency

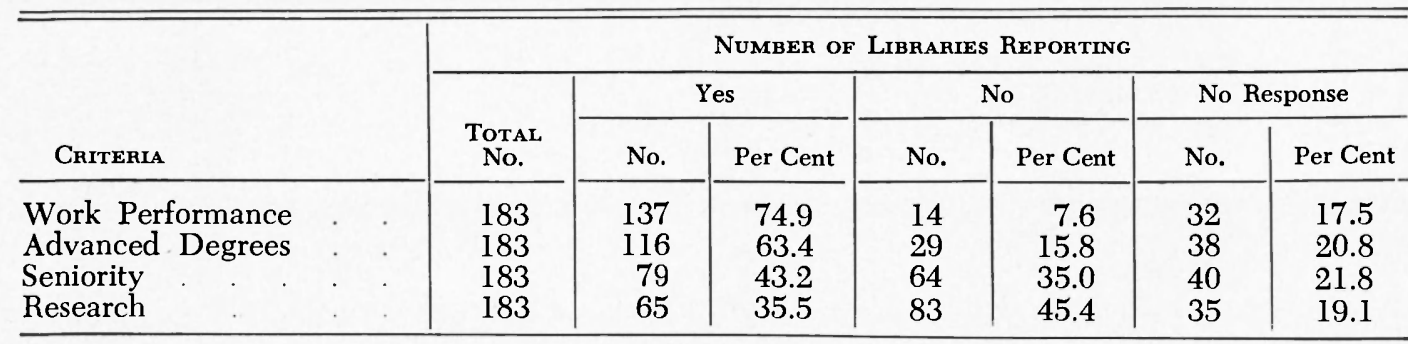

sixty-five, or 35.5 per cent, of the institutions attached some importance to research and publications by librarians, which might be due to the fact that many administrators do not free librarians from their duties to work on independent research projects.

\section{ConCLUSION}

It is unfortunate, but nonetheless true, that the conditions of librarians have not changed significantly over the past decade. Even though 63.4 per cent of librarians polled reported that they had status, findings indicate that they did not. The yardstick by which the committee measured the librarians' faculty status might be considered by some to be too rigid. This is indicated by the repeated responses from our colleagues saying "we are equal to faculty, except. ..." These statements suggest that librarians themselves may be somewhat responsible for their position on a low rung of the academic ladder. They are willing to settle for less than equal status, and some even seem resigned to their fate. "We are just rendering a service," one respondent wrote. "We have sacrificed to learn, but feel that except for appreciation from alumni and students, the administration does not know we are here." Another stated, "Librarians have been conned into thinking it is vulgar and unprofessional to care about status and rank."

The institutions of higher education must also bear some of the blame, for they have rightfully insisted upon upgrading libraries and librarians and their qualifications, but many have ignored the pleas of librarians to be treated at par with the rest of the faculty of which they are an integral part. Neither can the academic community be absolved from the responsibility of holding librarians at an unequal and unjust level. Each time the question of equal status for librarians arises the teaching faculty creates an uproar as if the attainment of status is their sole right and extending the same privileges to others is an infringement of this right.

If librarians are to improve their own situation, they and their professional organizations must work toward gaining their proper place in the academic community. This implies that librarians must accept the fact that "full faculty status" brings with it not only equal privileges but also the obligations of research and advanced degrees which have become synonymous with faculty status. The American Library Association has not taken a strong stand on this issue. This is unlike the action taken by other professional organizations, such as the American Association of University Professors, which has played an active role in ameliorating the conditions of academic faculties. The granting of "full faculty status" by the colleges throughout the nation appears to be one of the imperative actions to be pursued in alleviating the acute shortage of academic librarians. 